Article

\title{
Two-Step Size-Exclusion Nanofiltration of Prothrombin Complex Concentrate Using Nanocellulose-Based Filter Paper
}

\author{
Levon Manukyan ${ }^{1}\left(\mathbb{D}\right.$, Athanasios Mantas $^{1}{ }^{(D)}$, Mikhail Razumikhin ${ }^{2}$, Andrey Katalevsky ${ }^{3}$, \\ Eugen Golubev ${ }^{4}$ and Albert Mihranyan ${ }^{1, *(D)}$ \\ 1 Nanotechnology and Functional Materials, Department of Materials Science and Engineering, \\ Uppsala University, Box 534, 75121 Uppsala, Sweden; levon.manukyan@angstrom.uu.se (L.M.); \\ athanasios.mantas@angstrom.uu.se (A.M.) \\ 2 Nacimbio JC, 10, 2nd Volkonsky lane, 127473 Moscow, Russia; razumikhin.m@gmail.com \\ 3 Biopharmgarant LLC, Stancionnaya 45, 600901 Vladimir, Russia; andreyalexandr2003@yandex.ru \\ 4 National Research Center for Hematology, Novyi Zykovskiy proezd 4, 125167 Moscow, Russia; \\ ev-genius@bk.ru \\ * Correspondence: albert.mihranyan@angstrom.uu.se; Tel.: +46-18-471-7940
}

Received: 29 February 2020; Accepted: 21 March 2020; Published: 26 March 2020

\begin{abstract}
Coagulation Factor IX-rich protrhombin complex concentrate (FIX-PCC) is a therapeutic biologic product that consists of a mixture of several human plasma-derived proteins, useful for treating hemophilia B. Due to its complex composition, FIX-PCC is very challenging to bioprocess through virus removing nanofilters in order to ensure its biosafety. This article describes a two-step filtration process of FIX-PCC using a nanocellulose-based filter paper with tailored porosity. The filters were characterized with scanning electron microscopy (SEM), cryoporometry with differential scanning calorimetry, and nitrogen gas sorption. Furthermore, in order to probe the filter's cut-off size rejection threshold, removal of small- and large-size model viruses, i.e., $\Phi X 174$ (28 nm) and PR772 (70 nm), was evaluated. The feed, pre-filtrate, and permeate solutions were characterized with mass-spectrometric proteomic analysis, dynamic light scattering (DLS), sodium dodecyl sulfate-polyacrylamide gel electrophoresis (SDS-PAGE), and analytical size-exclusion high-performance liquid chromatography (SEHPLC). By sequential filtration through $11 \mu \mathrm{m}$ pre-filter and $33 \mu \mathrm{m}$ virus removal filter paper, it was possible to achieve high product throughput and high virus removal capacity. The presented approach could potentially be applied for bioprocessing other protein-based drugs.
\end{abstract}

Keywords: Mille-feuille filter; Cladophora cellulose; hemophilia B; protein aggregates; virus removal filtration

\section{Introduction}

Replacement therapy using plasma-derived Factor IX (FIX) products is a life-saving treatment for patients with hemophilia B. Both recombinant and plasma-derived FIX show high efficacy in clinical trials [1]. Production of FIX normally involves multiple steps. High purity FIX is obtained from prothrombin complex concentrate (PCC), which is a mixture of vitamin K-dependent clotting factors, e.g., factor II (prothrombin), V, VII, IX, and X, and clotting inhibitors, e.g., protein C, Z, and S [2]. PCC preparation is a highly complex mixture of proteins and may contain up to $50 \%$ of proteins other than FIX [3]. Both highly purified FIX and PCC can be used for hemophilia B treatment [4]. Also, PCC preparation may be useful for prevention of bleeding due to overdose of oral anticoagulants and liver dysfunctions [2,3]. 
As it is with all plasma-derived products, the viral safety of FIX-rich PCC is a critical issue [5]. According to current regulations, at least two orthogonal virus clearance steps must be implemented to ensure viral safety of the final product [6]. The steps to mitigate virus contamination of FIX and PCC products include donor screening for known blood-borne viruses, i.e., HIV 1-2, HBV, HCV, HAV, and parvo B19; virus inactivation, such as solvent/detergent, mixed chemical inactivation (tri-n-butyl phosphate) and detergent (nonionic, polysorbate, and polyethylene oxide) treatment; and incubating intermediate product in controlled temperature (usually $6 \mathrm{~h}$ at $25^{\circ} \mathrm{C}$ ) $[3,7,8]$. Dry heat treatment may also be used after lyophilization, e.g., $100{ }^{\circ} \mathrm{C}$ for $1 \mathrm{~h}$ or $80{ }^{\circ} \mathrm{C}$ for $72 \mathrm{~h}$. In the past, steam treatment at $60{ }^{\circ} \mathrm{C}(190 \mathrm{mbar})$ for $10 \mathrm{~h}$ or $80{ }^{\circ} \mathrm{C}$ (375 mbar) for $1 \mathrm{~h}$ was reported [3,7,8]. Presently, virus removal nanofiltration has become widely used as a robust and reliable method for ensuring viral safety. Nanofiltration is attractive because it is capable of physically removing all types of viruses from protein solution as opposed to virus inactivation. Several authors have described the application of virus removal nanofiltration for FIX industrial products using Planova 15/20/35N [9-15], Viresolve NFP [11,16-19], and Ultipor DV50 filters [2]. The conclusion of these studies is that filtration of plasma-derived FIX-rich products is challenging due to the presence of large molecular weight impurities and protein aggregates.

It is known that the levels of different impurities are highly dependent on the type of chromatographic separation that was used during plasma treatment $[3,18,20]$. The most extensively described impurities in vitamin K-dependent clotting factors include inter- $\alpha$-trypsin-inhibitor (ITI), complement $4 \mathrm{~b}$ binding protein $(\mathrm{C} 4 \mathrm{BP})$, and vitronectin $(\mathrm{VN})$. C4BP is a large glycoprotein of $570 \mathrm{kDa}[21]$ in the shape of an octopus that consists of seven $\alpha$-chains connected to a single $\beta$-chain by disulfide bonds [22-24]. The $\alpha$-chains are responsible for binding $C 4 b$, while the $\beta$-chain has high-affinity for VN (protein S), forming large complexes [22,25]. The molecular conformation of C4BP is highly dependent on the surrounding medium composition [11,19]. In the charged state the $\alpha$-chains repel each other, thereby occupying much larger volume than the same molecule in the uncharged state. In its open structure form, C4BP would have a diameter of approximately $66 \mathrm{~nm}$ since each $\alpha$-chain arm is $33 \mathrm{~nm}$ long [11,22]. Varying salt concentrations have been shown to affect the compactness of C4BP molecule and thereby the flux properties of the virus removal filter [19]. Another large Mw impurity present often in FIX products is ITI. ITI $(225 \mathrm{kDa})$ is a large complex that consists of one light and several heavy chains (H1-H3) covalently linked by a chondroitin sulfate chain. The heavy chains of ITI proteins function as hyaluronic acid (HA) binding proteins, whereas the light chain, also called bikunin, functions as a serine protease inhibitor upon activation [26]. The third extensively described impurity is VN [27]. The monomeric form of VN has a cryptic hydrophobic pocket, which upon exposure and conformational changes exhibits heparin- and C5b-7 binding activity [28]. Normally, only $2 \%$ of $\mathrm{VN}$ in plasma shows heparin-binding activity but its fraction increases manifold during coagulation [29]. VN also presents a free thiol group capable of disulfide bonding [30]. When unfolded $\mathrm{VN}$ is highly prone to polymerization and may form aggregates with Mw up to $1000 \mathrm{kDa}$ [28]. Studies on nanofiltration of FIX products where VN aggregates were detectable confirmed its role as a filter foulant [27]. Extensive coverage of various impurities at different intermediate stages during FIX manufacturing is discussed elsewhere [15,18].

So far successful virus removal filtration of FIX products has been described in the literature only for a limited number of commercial filters. A novel type of virus removal filter paper was developed at Uppsala University, which is produced by adapting traditional paper making technology and consists of $100 \%$ cellulose nanofibers [31,32]. The pore size and flux properties of the filter paper can be controlled, which opens new opportunities to model fundamental aspects of bioprocessing [32-34]. The filter paper was previously validated in numerous studies to remove several large and small-size model viruses, including retroviruses (xMuLV, $100 \mathrm{~nm}$ ) [35], parvoviruses (MVM, $20 \mathrm{~nm}$ ) [32,36], and model phages $(\Phi X 174,28 \mathrm{~nm})$ [37-39]. Recently, it was shown that this nanocellulose-based virus removal filter paper is useful for bioprocessing human plasma-derived IgG [40]. 
In this article, for the first time the filtration of FIX-rich PCC using a nanocellulose-based virus removal filter paper is described. Furthermore, a two-step size-exclusion nanofiltration process is developed to remove foulants and ensure efficient virus removal filtration of FIX-rich PCC using nanocellulose-based virus removal filter paper. FIX-rich PCC was used as a model for a highly complex plasma-derived product to simulate industrial bioprocesses where impurities may greatly affect product yield and biosafety.

\section{Materials and Methods}

\subsection{Materials}

Cladophora cellulose was provided by FMC Biopolymer (batch 3095-10; Newark, DE, USA). FIX-rich PCC was provided by National Center for Hematology, Moscow, Russia, as lyophilized powder. Coliphages $\Phi X 174$ (ATCC 13706-B1 ${ }^{\mathrm{TM}}$ ) and PR772 (BAA-769-B1), and the host bacteria Escherichia coli (Migula) Castellani and Chalmers C (ATCC 13706) and K12 J53-1(R15) [HER 1221] (BAA-769) strains were obtained from ATCC (Manassas, VA, USA). Agar (214530) was obtained from BD (Franklin Lakes, NJ, USA). Tryptone (LP0042B) and yeast extract (Oxoid) (LP0021) were obtained from Thermo Fisher Scientific. Phosphate-buffered saline (P4417), 2-mercaptoethanol (M3148), sodium chloride (S5886), sodium phosphate dibasic (71640) and 2-mercaptoethanol (M3148) were purchased from Sigma-Aldrich (Saint Louis, MO, USA). Any kD ${ }^{\mathrm{TM}}$ Mini-PROTEAN $^{\circledR}$ TGX Stain-Free $^{\mathrm{TM}}$ protein gels (4568125), tris/glycine/SDS running buffer (1610732), 4x Laemmli Sample Buffer (1610747), and Precision Plus Protein ${ }^{\mathrm{TM}}$ unstained protein standards (1610363) were purchased from Bio-Rad (Hercules, CA, USA).

\subsection{Filter Preparation}

Filters of different thickness were prepared from Cladophora cellulose dispersion (0.1 wt.\%) made by microfluidization with $200 \mu \mathrm{m}$ (twice) and $100 \mu \mathrm{m}$ hole sized chambers at 1800 bar using LM20 Microfluidizer (Microfluidics, Westwood, MA, USA). Furthermore, the wet cake was made by draining the dispersion over a membrane (Durapore, $0.65 \mu \mathrm{m}$ hydrophilic PVDF "DVPP", Merck Millipore, Burlington, MA, USA) in a funnel, driven by vacuum. Obtained cellulose cakes were dried at $140{ }^{\circ} \mathrm{C}$ to produce pre-filters and $80{ }^{\circ} \mathrm{C}$ for filter papers using hot-press (Carver Model $4122 \mathrm{CE}$, Carver, Wabash, IN, USA).

\subsection{Dissolution of Factor IX-rich PCC}

Lyophilized FIX-rich PCC samples were reconstituted by dissolving in phosphate-buffered saline (PBS). No visible particles could be seen after reconstitution, and the solution was clear and transparent. Upon dissolution, the conductivity and $\mathrm{pH}$ values were $15.4 \mathrm{mS} \mathrm{cm}^{-1}$ and 7.4 , respectively.

\subsection{Filtration Setup}

Pre-filtration and filtration steps were performed in a $47 \mathrm{~mm}$ diameter Advantech KST 47 filter holder. Prior to filtration, the pre- and filter papers were wetted in order to extrude the air by running $20 \mathrm{~mL}$ of PBS. The pre-filtration steps with 6 and $11 \mu \mathrm{m}$ pre-filters were performed at 1 bar transmembrane pressure, and the filtrations with $33 \mu \mathrm{m}$ filters were carried out at 1 or 3 bar. The permeate solutions were collected and for filtrations of the larger volume, permeate was collected in one or three fractions and saved.

\subsection{Scanning Electron Microscopy (SEM)}

For top-view images samples were fixed onto aluminum stubs with double-adhesive carbon tape, and for cross-section images the samples were mounted onto aluminum sample holders with screw. Imaging was performed using Zeiss Merlin FEG-SEM instrument (Jena, Germany). To reduce charging 
effects samples were sputtered with $\mathrm{Au} / \mathrm{Pd}$ with a sputter coater (Polaron, Ashford, UK) was used. The sputtering settings were $4 \times 10^{2} \mathrm{mbar}$ and $35 \mathrm{~mA}$, and the sputtering time was $30 \mathrm{~s}$.

\subsection{Cryoporometry by Differential Scanning Calorimetry}

Filter paper samples (1.5-2 $\mathrm{mg}$ ) were soaked into deionized water overnight at room temperature. Water was decanted, and the samples were placed in aluminum crucibles with a lid. Samples were cooled down to $248.15 \mathrm{~K}\left(-25^{\circ} \mathrm{C}\right)$ at a rate of $10 \mathrm{~K} \mathrm{~min}^{-1}$ followed by heating to $277.15 \mathrm{~K}\left(4^{\circ} \mathrm{C}\right)$ at a rate of $0.7 \mathrm{~K} \mathrm{~min}^{-1}$. Measurements were performed in five replicates.

The pore size was calculated according to Landry [41]:

$$
\Delta T=-\frac{19.082}{r_{p}-1.12}-0.1207
$$

where $r_{p}$ is the radius of pore $(\mathrm{nm})$ and $\Delta T$ is the difference between the peak maximum for melting of pore-confined water and peak value for melting of bulk water, experimentally determined at $0.6 \pm 0.01{ }^{\circ} \mathrm{C}$.

\subsection{Dynamic Light Scattering}

Particle size distribution was obtained from dynamic light scattering (DLS) using a Zetasizer Nano ZS (Malvern, UK) instrument. All experiments were performed in triplicates.

\subsection{Polyacrylamide Gel Electrophoresis}

Protein separation was performed by reducing polyacrylamide gel electrophoresis (SDS-PAGE). Samples were diluted (1:20 v/v) with PBS and Laemmli buffer, and boiled for $10 \mathrm{~min}$. Electrophoretic separation was carried out at $270 \mathrm{~V}$ with Mini-PROTEAN Tetra Vertical Electrophoresis Cell (Bio-Rad, Hercules, CA, USA). Protein bands were detected with Gel Doc ${ }^{\mathrm{TM}}$ EZ System (Bio-Rad, Hercules, CA, USA), and quantified using Image Lab 6.0 analysis software (Bio-Rad).

\subsection{Analytical SEHPLC}

Samples were analyzed by size-exclusion high-pressure liquid chromatography using Hitachi Chromaster HPLC-UV system with bioZen $1.8 \mu \mathrm{m}$ SEC-3 (Phenomenex, Torrance, CA, USA) analytical column. Chromatography was performed with $100 \mathrm{mM}$ sodium phosphate, $\mathrm{pH} 6.8$ mobile phase at $0.3 \mathrm{~mL} \mathrm{~min}^{-1}$ flow rate for $20 \mathrm{~min}$.

\subsection{LCMS}

Equal amounts $(20 \mu \mathrm{g})$ of protein samples were taken out for digestion. After reduction and alkylation, the proteins were on-filter digested by trypsin using $3 \mathrm{kDa}$ centrifugal filters (Millipore Tullagreen, Ireland) according to a standard operating procedure. Obtained peptides were dried using a speedvac system. Pellets were resolved in $60 \mu \mathrm{L}$ of $0.1 \%$ formic acid and further diluted four times prior to nano-LCMS/MS. Tandem mass spectrometry was performed by applying HCD in the QEx-Orbitrap mass spectrometer (Thermo Finnigan, San Jose, CA, USA), equipped with a reversed-phase C18-column by 35 min long gradient.

Database searches were performed using the Sequest algorithm, embedded in Proteome Discoverer 1.4 (Thermo Fisher Scientific, Waltham, MA, USA) against Homo Sapience proteome extracted from Uniprot, Release June 2019 with 95\% confidence level per protein.

\subsection{Bacteriophage Filtration and Titration}

Coliphages PR772 and $\Phi$ X174 were spiked to the pre-filtered solutions to obtain final titer about $10^{6}$ plaque forming units (PFU) $\mathrm{mL}^{-1}$ before filtration was performed. Bacteriophage titer was determined by PFU assay by double agar overlay method. Briefly, ten-fold serially diluted bacteriophage samples 
were mixed with host $E$. coli strains and melted soft agar, and poured on the surface of prepared hard agar plate, followed by incubation at $37^{\circ} \mathrm{C}$ for $5 \mathrm{~h}$.

Bacteriophage titer was calculated using Equation (1):

$$
\log _{10}\left(P F U \mathrm{~mL}^{-1}\right)=\log _{10}\left(\frac{N}{\mathrm{~V} \cdot \mathrm{d}}\right)
$$

where $N$ is the number of plaques, $\mathrm{V}$ is the volume (typically $0.1 \mathrm{~mL}$ ) of added virus and $\mathrm{d}$ is the dilution factor.

The virus retention was expressed as $\log _{10}$ reduction value $(L R V)$ :

$$
L R V=\log _{10} \frac{P F U_{\text {feed }}}{P F U_{\text {permeate }}}
$$

\section{Results}

\subsection{One-Step $33 \mu \mathrm{m}$ Filtration of FIX-Rich PCC}

When the FIX-rich PCC at $20 \mathrm{~L} \mathrm{~m}^{-2}$ volumetric load was filtered through the $33 \mu \mathrm{m}$ mille-feuille filter paper, a rapid flux decline was observed, e.g., from about $80 \mathrm{~L} \mathrm{~m}^{-2} \mathrm{~h}^{-1}$ to about $10 \mathrm{~L} \mathrm{~m}^{-2} \mathrm{~h}^{-1}$ at 3 bar overhead pressure. DLS analysis of the feed and permeate samples revealed that the feed sample showed widely distributed fraction of protein impurities above $70 \mathrm{~nm}$, which were not detectable after filtration as shown in Figure 1. Notably, these large-size impurities could not be detected in the volume distribution profiles of the feed sample but only in the intensity distribution plots, which suggests that the original amount of the aggregates is small. In the permeate sample, no particle fractions above $40 \mathrm{~nm}$ were detected by DLS.
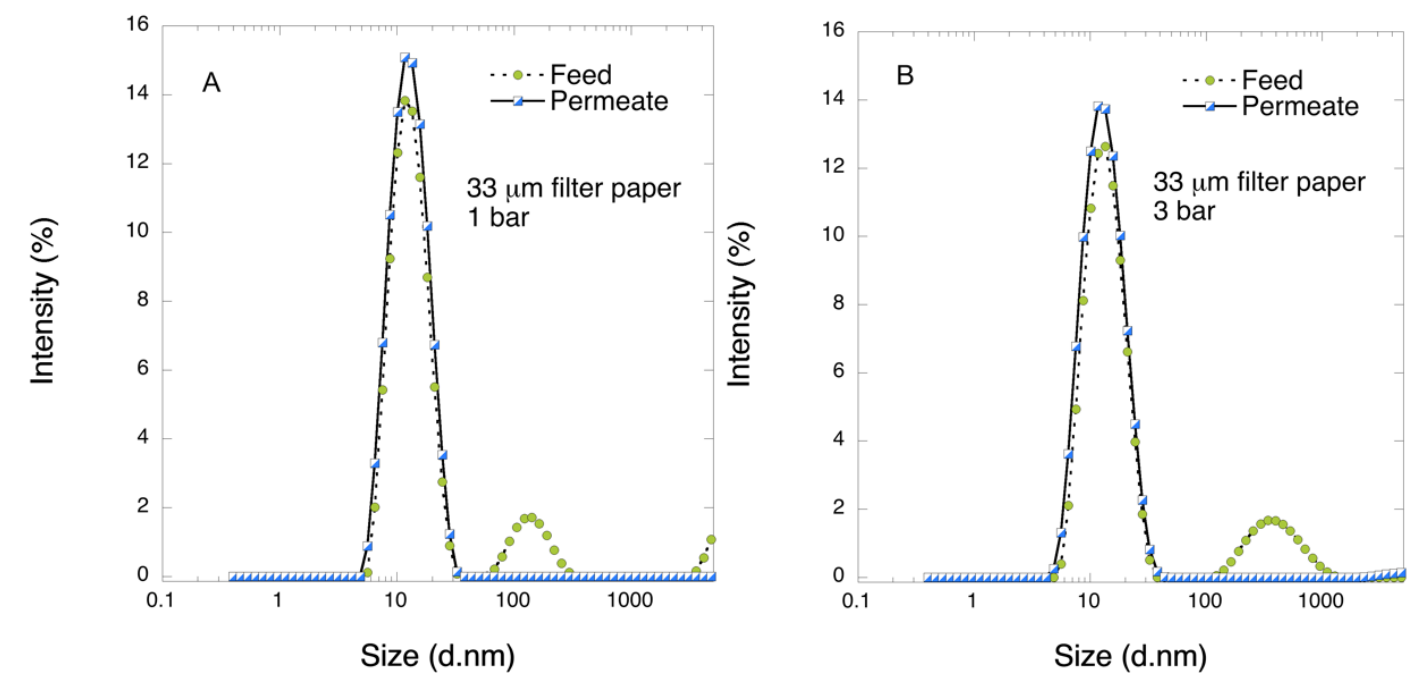

Figure 1. DLS profiles of feed and permeate samples after 1-step filtration through $33 \mu \mathrm{m}$ filter paper at 1 and 3 bar.

To investigate if significant changes were recorded in the protein molecular weight distribution in the permeate sample, SDS-PAGE analysis was performed, as shown in Figure 2. Additional proteomics analysis of the detected bands was not performed as it was outside of the scope of the present work. It is seen in Figure 2 that all major fractions in the permeate sample were reduced compared to the feed. The observed decrease in total protein fraction is concordant to that reported earlier for PCC product filtered through Planova $15 \mathrm{~N}$ filter [14]. In all, it appears that the large molecular weight protein fractions are the main reason for the observed fouling. 

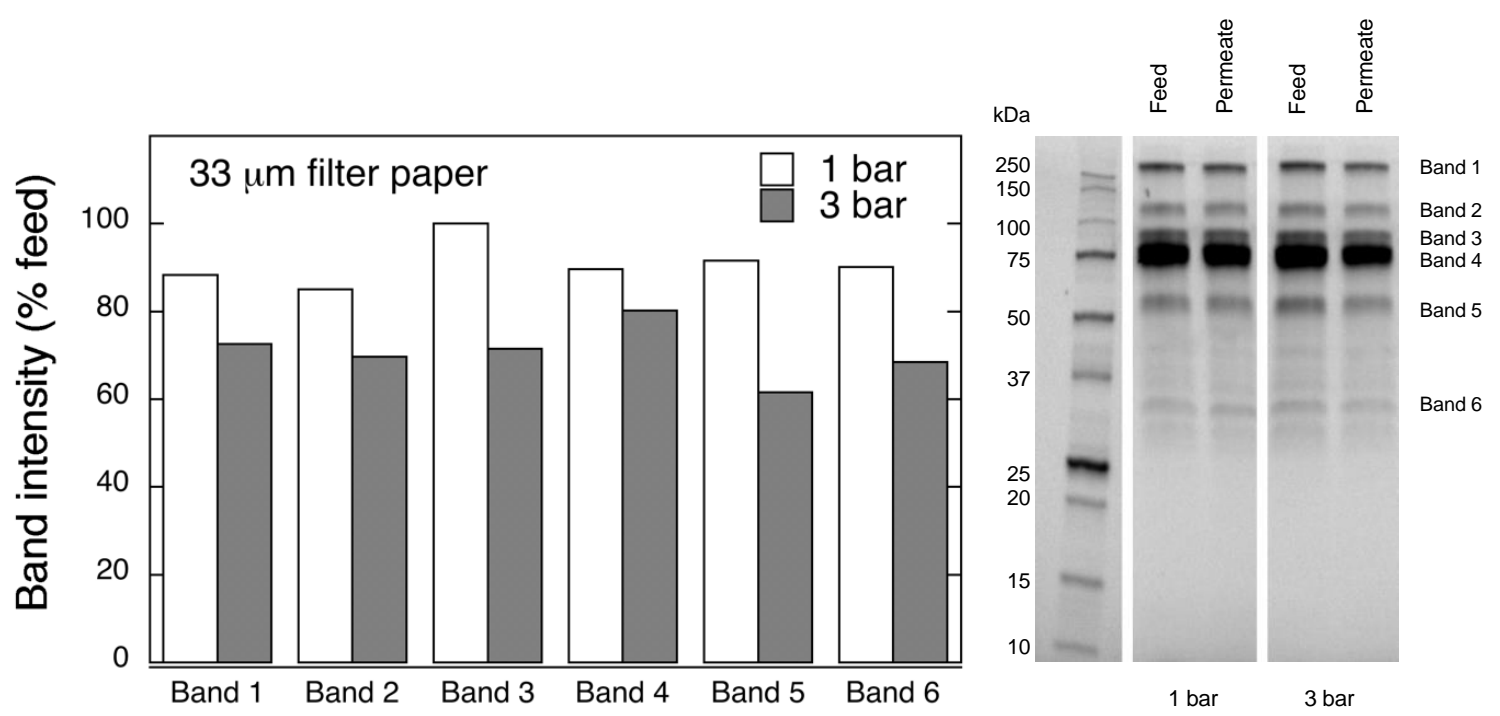

Figure 2. SDS-PAGE analysis of permeate fractions after 1 step filtration through $33 \mu \mathrm{m}$ filter paper at 1 and 3 bar.

\subsection{Development and Validation of Two-Step Size-Exclusion Bioprocess for FIX-Rich PCC Nanofiltration}

The nanocellulose-based filter paper platform provides the possibilities to relatively easily tailor the pore-size distribution of the filter paper to a specific cut-off value. This could be achieved for instance by varying the thickness of the filter paper.

Figure 3 shows the SEM images of the filters with varying thickness, including their top-view and cross-section. It is seen from the images of the cross-sections of the filters that they indeed feature varying thicknesses.
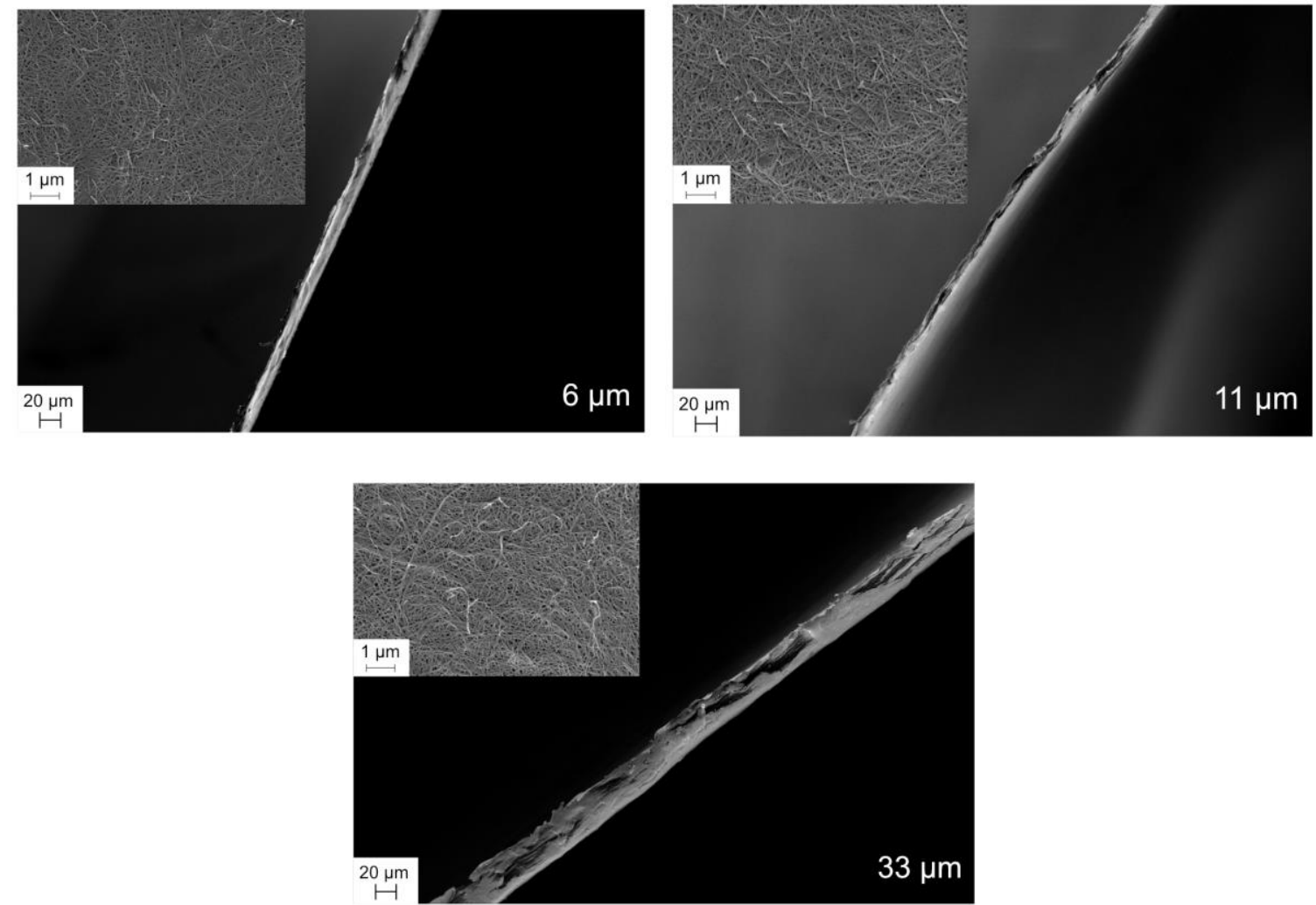

Figure 3. SEM images of top-view and cross-sections of 6,11 , and $33 \mu \mathrm{m}$ filter papers. 
To derive information about the pore size of the filter cryoporometry analysis was performed. Figure 4 shows the typical CP-DSC curves of the studied samples and the boxplots of the derived pore width modes. Cryoporometry analysis has the benefit that it probes the pores in the wet state, and it is a relatively quick and highly automated and reliable method. In this method, the samples are first frozen to $-40{ }^{\circ} \mathrm{C}$ and then slowly thawed. As the ice crystals start to melt, there is a detectable endotherm peak. When the water is located inside mesopores (i.e., 2-50 nm pore width), there will be a melting point depression as opposed to bulk water, present outside pores or in macropores (above $50 \mathrm{~nm}$ ). In our experiments, bulk water melts at around $0.6^{\circ} \mathrm{C}$. The larger the melting point depression, the smaller are the pores. As seen from Figure 4 there is a trend of decreasing pore width mode with increasing thickness.
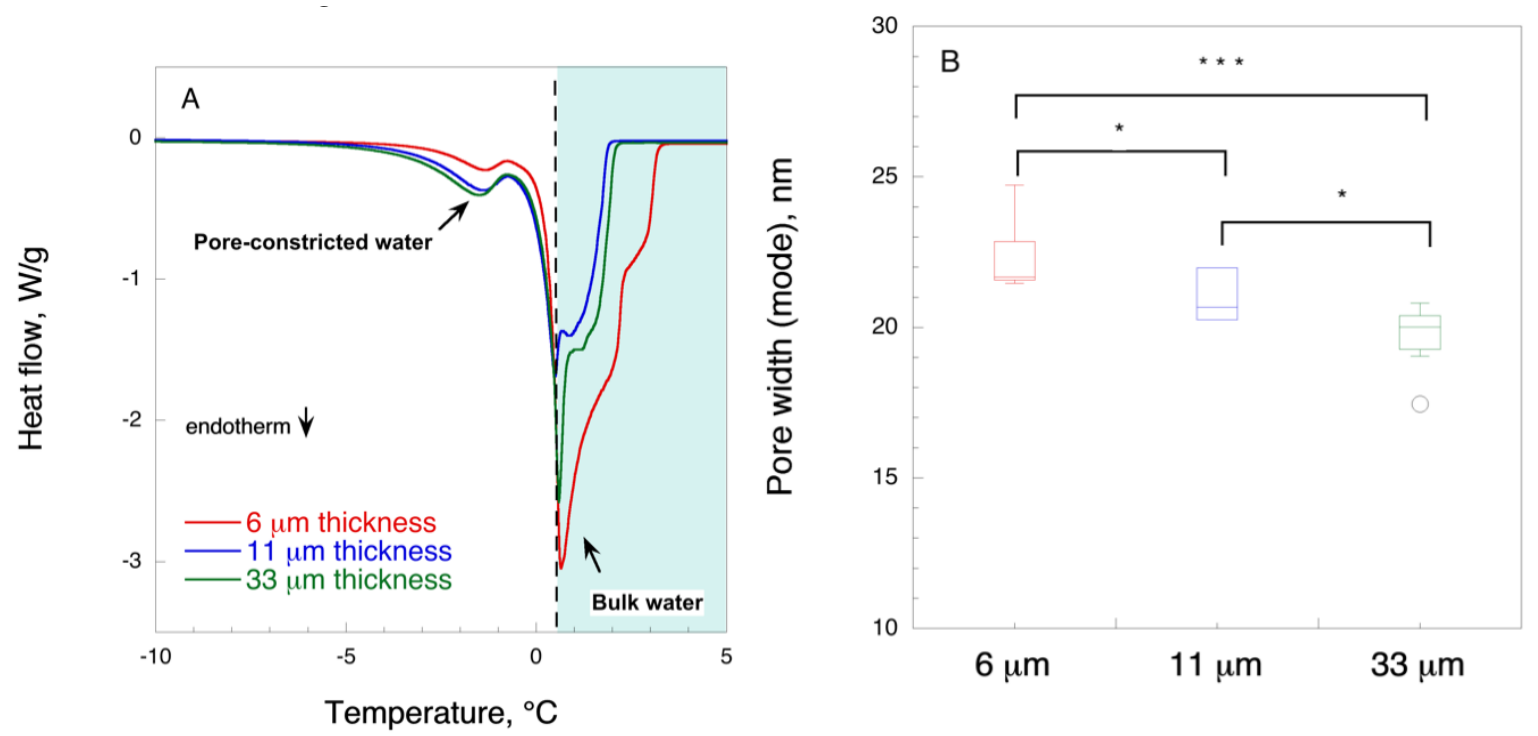

Figure 4. Typical cryoporometry DSC curves (A) and boxplot of pore width modes (B) for 6, 11, and $33 \mu \mathrm{m}$ filter papers $(n=7) .{ }^{*} p<0.05,{ }^{* * *} p<0.01$.

To assess the particle rejection cut-off for each filter, model probes with 2 different particle sizes were used in the form of bacteriophages, i.e., PR772 $(70 \mathrm{~nm})$ and $\Phi X 174(28 \mathrm{~nm})$ phages, see Tables 1 and 2 , respectively. These probes provide a highly sensitive tool for assessing the size-dependent rejection capability of the filters with varying thickness, i.e., 6,11 , and $33 \mu \mathrm{m}$. The $33 \mu \mathrm{m}$ mille-feuille filter paper shows the lowest hydraulic flux, i.e., $38 \mathrm{~L} \mathrm{~m}^{-2} \mathrm{~h}^{-1} \mathrm{bar}^{-1}$, and the highest virus removal capacity for both small- and large-size viruses, i.e., LRV $\geq 5.7$. The $6 \mu \mathrm{m}$ filter in the series exhibits the fastest flux, i.e., $405 \mathrm{~L} \mathrm{~m}^{-2} \mathrm{~h}^{-1}$ bar $^{-1}$, but poor virus removal capacity, i.e., LRV $<1$ and $<2$ for $28 \mathrm{~nm}$ and $70 \mathrm{~nm}$ model phages. The flux and virus removal properties of $11 \mu \mathrm{m}$ filter are intermediate to the other two filters, wherein the $11 \mu \mathrm{m}$ filter paper shows high clearance towards $70 \mathrm{~nm}$ virus, i.e., $>5.7$, and moderate clearance toward $28 \mathrm{~nm}$ one, i.e., LRV 3.5-4.5, and hydraulic flux of $125 \mathrm{~L} \mathrm{~m}^{-2} \mathrm{~h}^{-1}$ bar $^{-1}$. Interestingly, the small-size virus removal capacity of $11 \mu \mathrm{m}$ filter decreased with increasing load volume, whereas that of $33 \mu \mathrm{m}$ filter remained unaffected under the experimental conditions. The latter could probably be due to redistribution of flow through the larger pores when the smaller pores become clogged in $11 \mu \mathrm{m}$ filter paper. 
Table 1. LRVs for $70 \mathrm{~nm}$ (PR772) bacteriophages filtered through 6, 11, and $33 \mu \mathrm{m}$ filter papers. The results represent the virus clearance data of virus-spiked PBS. Green color code denotes high virus clearance LRV > 5; Yellow denotes moderate virus clearance $(2<\mathrm{LRV}<5)$; and pink denotes low virus clearance $(\mathrm{LRV}<1)$.

\begin{tabular}{|c|c|c|c|}
\hline \multirow{2}{*}{ Thickness ( $\mu \mathrm{m})$} & \multicolumn{3}{|c|}{ Load Volume } \\
\hline & $7.5 \mathrm{~L} \mathrm{~m}^{-2}$ & $15 \mathrm{~L} \mathrm{~m}^{-2}$ & $23 \mathrm{~L} \mathrm{~m}^{-2}$ \\
\hline 6 & $1.6 \pm 0.2$ & $1.3 \pm 0.1$ & $1.1 \pm 0.3$ \\
\hline 11 & $>5.5 \pm 0.2$ & $>5.5 \pm 0.2$ & $>5.5 \pm 0.2$ \\
\hline 33 & $>5.7 \pm 0.2$ & $>5.7 \pm 0.2$ & $>5.7 \pm 0.2$ \\
\hline
\end{tabular}

Table 2. LRVs for $28 \mathrm{~nm}(\Phi X 174)$ bacteriophages filtered through 6, 11, and $33 \mu \mathrm{m}$ filter papers. The results represent the virus clearance data of virus-spiked PBS. Green color code denotes high virus clearance LRV > 5; Yellow denotes moderate virus clearance $(2<\mathrm{LRV}<5)$; and pink denotes low virus clearance $(\mathrm{LRV}<2)$.

\begin{tabular}{|c|c|c|c|}
\hline \multirow{2}{*}{ Thickness $(\mu \mathrm{m})$} & \multicolumn{3}{|c|}{ Load Volume } \\
\hline & $7.5 \mathrm{~L} \mathrm{~m}^{-2}$ & $15 \mathrm{~L} \mathrm{~m}^{-2}$ & $23 \mathrm{~L} \mathrm{~m}^{-2}$ \\
\hline 6 & $0.7 \pm 0.3$ & $0.8 \pm 0.3$ & $0.8 \pm 0.2$ \\
\hline 11 & $4.5 \pm 0.5$ & $3.7 \pm 0.4$ & $3.5 \pm 0.7$ \\
\hline 33 & $>5.7 \pm 0.4$ & $>5.7 \pm 0.4$ & $5.7 \pm 0.4$ \\
\hline
\end{tabular}

\subsection{Two-Step $6 \mu \mathrm{m} / 33 \mu \mathrm{m}$ Filtration of FIX-Rich PCC}

Figure 5 shows the permeate flux through the $6 \mu \mathrm{m} / 33 \mu \mathrm{m}$ filtration sequence at 1 bar. Rapid flux decline was observed for the permeate after initial plateau. Please note that the flux of pre-filtrate was so fast that it was not recorded.

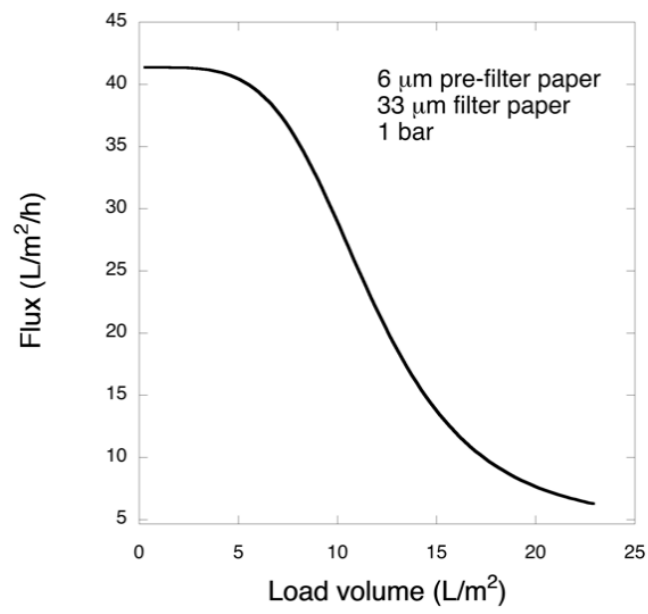

Figure 5. Observed permeate flux for two-step $6 \mu \mathrm{m} / 33 \mu \mathrm{m} \mu \mathrm{m}$ filtration at 1 bar.

Figure 6 shows the DLS results for pre-filtrate and permeate samples for the $6 \mu \mathrm{m} / 33 \mu \mathrm{m}$ filtration sequence at 1 bar. It was observed the fraction of large colloids was not removed by $6 \mu \mathrm{m}$ pre-filtration. However, no aggregates were observed in the permeate sample after filtration through $33 \mu \mathrm{m}$ filter. 


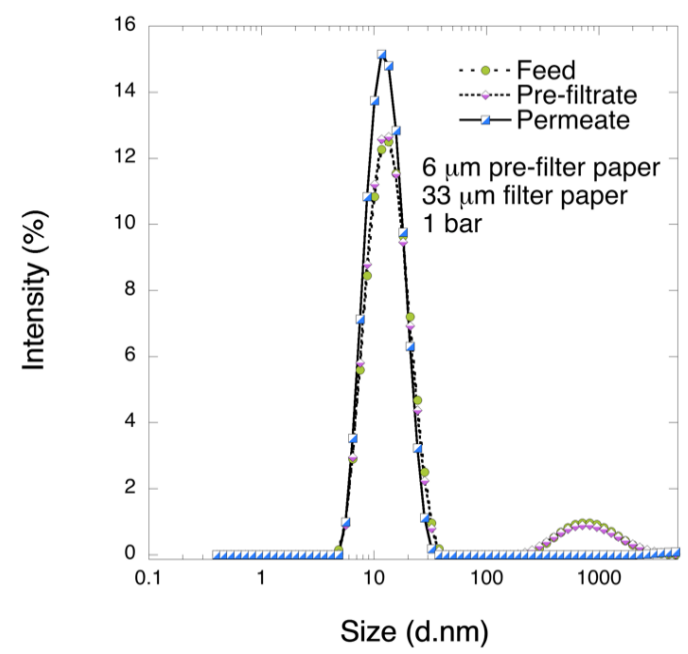

Figure 6. DLS analysis $11 \mu \mathrm{m}$ filter with further filtration with $33 \mu \mathrm{m}$ filter at 1 bar TMP DLS profiles of feed, pre-filtrate, and permeate samples after 2-step filtration through $11 \mu \mathrm{m} / 33 \mu \mathrm{m}$ filter paper at 1 bar.

Figure 7 shows the results of SDS-PAGE analysis of the collected samples. It is seen from the graph that all bands showed decreasing intensity. Even after $6 \mu \mathrm{m}$ pre-filtration, some decline in the band intensity was observed. The bands for lower Mw fractions, i.e., bands 4-6, were reduced to a greater extent after pre-filtration than those of the larger Mw, i.e., bands 1-3. In the permeate sample all band intensities were further decreased. LCMS analysis suggested that key coagulation factors IX, $X, V$ as well as prothrombin were not removed following the two-step $6 \mu \mathrm{m} / 33 \mu \mathrm{m}$ filtration sequence, as shown in Appendix Tables A1-A3.
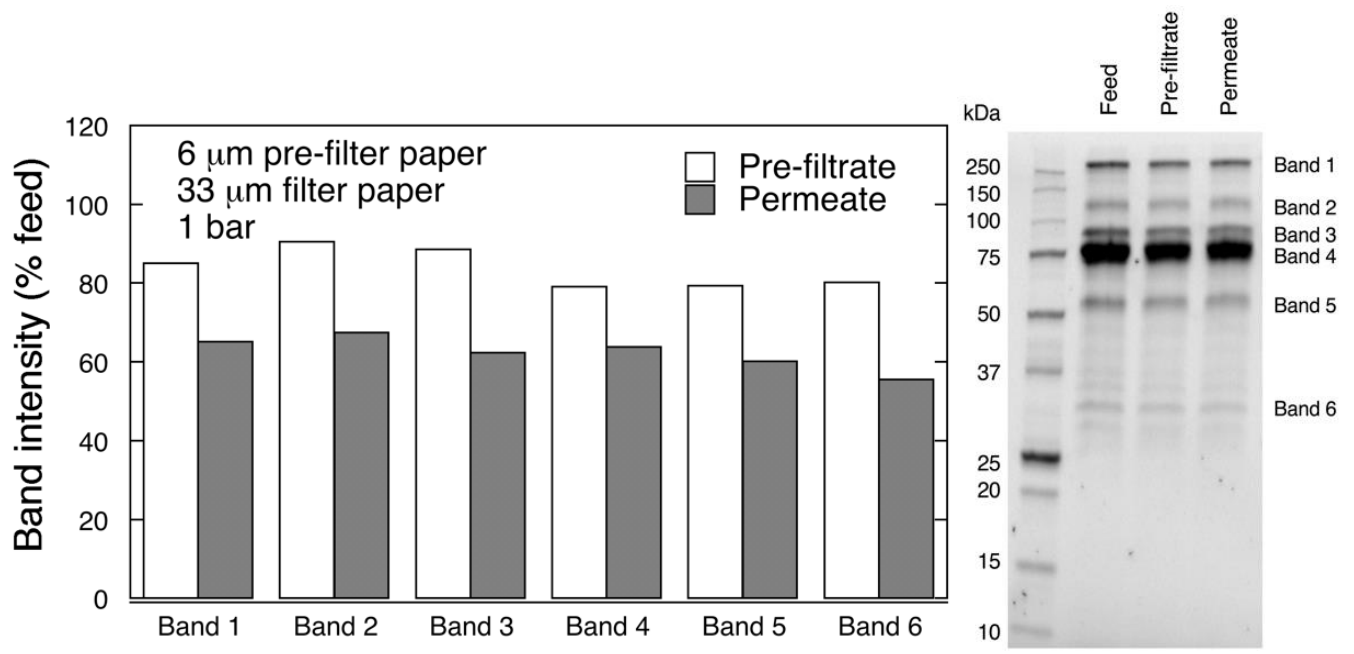

Figure 7. SDS-PAGE analysis of pre-filtrate and permeate fractions after 2-step filtration through $6 \mu \mathrm{m} / 33 \mu \mathrm{m}$ filter paper at 1 bar.

Overall, the results from the filtration with $6 \mu \mathrm{m} / 33 \mu \mathrm{m}$ sequence suggest that the large Mw impurities were not removed during the pre-filtration step and, subsequently, caused filter fouling and thereby low product yield during the second step.

\subsection{Two-Step $11 \mu \mathrm{m} / 33 \mu \mathrm{m}$ Filtration of FIX-Rich PCC}

In another set of experiments, the pre-filtration was performed using 11- $\mu \mathrm{m}$ filter paper followed by filtration with $33 \mu \mathrm{m}$ filter at 1 bar. Figure 8 shows the flux data of permeate for $11 \mu \mathrm{m} / 33 \mu \mathrm{m}$ filtration sequence. Increasing the thickness of the pre-filter from 6 to $11 \mu \mathrm{m}$ significantly affected the 
results. The flux values for pre-filtration indicated rapid fouling as observed above for $33 \mu \mathrm{m}$ filtration. However, in the second step of $11 \mu \mathrm{m} / 33 \mu \mathrm{m}$ filtration sequence, i.e., through $33 \mu \mathrm{m}$ filters, stable flux was observed for the entire processed volume, Figure 7 . The results contrast starkly those observed for $6 \mu \mathrm{m} / 33 \mu \mathrm{m}$ filtration sequence as shown in Figure 4.

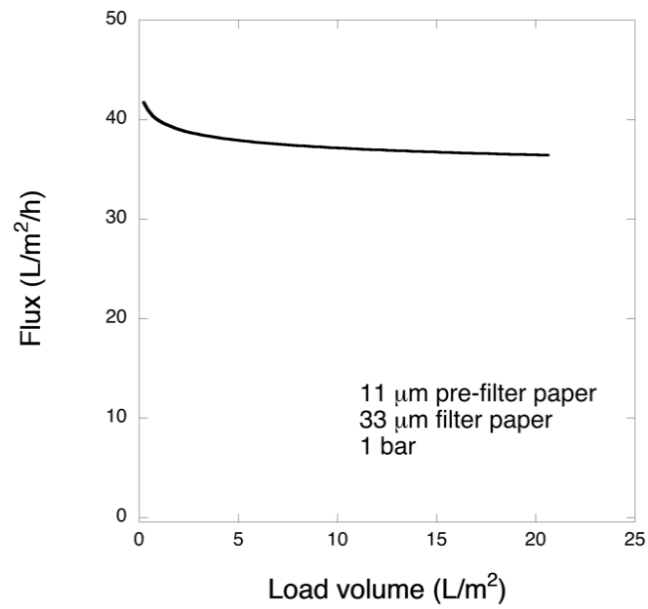

Figure 8. Observed permeate flux for two-step $11 \mu \mathrm{m} / 33 \mu \mathrm{m} \mu \mathrm{m}$ filtration at 1 bar.

Figure 9 shows the results of DLS analysis of the pre-filtrate and permeate samples. It is seen that the fraction of large-size impurities, which was clearly visible in the feed solution, was absent both in the pre-filtrate and permeate fractions of $11 \mu \mathrm{m} / 33 \mu \mathrm{m}$ filtration sequence. The latter suggests that pre-filtration with $11 \mu \mathrm{m}$ filter paper efficiently removes the large-size impurities, unlike pre-filtration with $6 \mu \mathrm{m}$ filter paper. Additional SEHPLC analysis was performed on these samples as shown in Figure 8. It is seen in the graph that the peak retention times and relative intensities are similar in all three samples except for the early peak at $0.5 \mathrm{~min}$ in the feed sample. This peak, which corresponds to the largest protein fraction was not detectable in pre-filtrate and permeate samples.
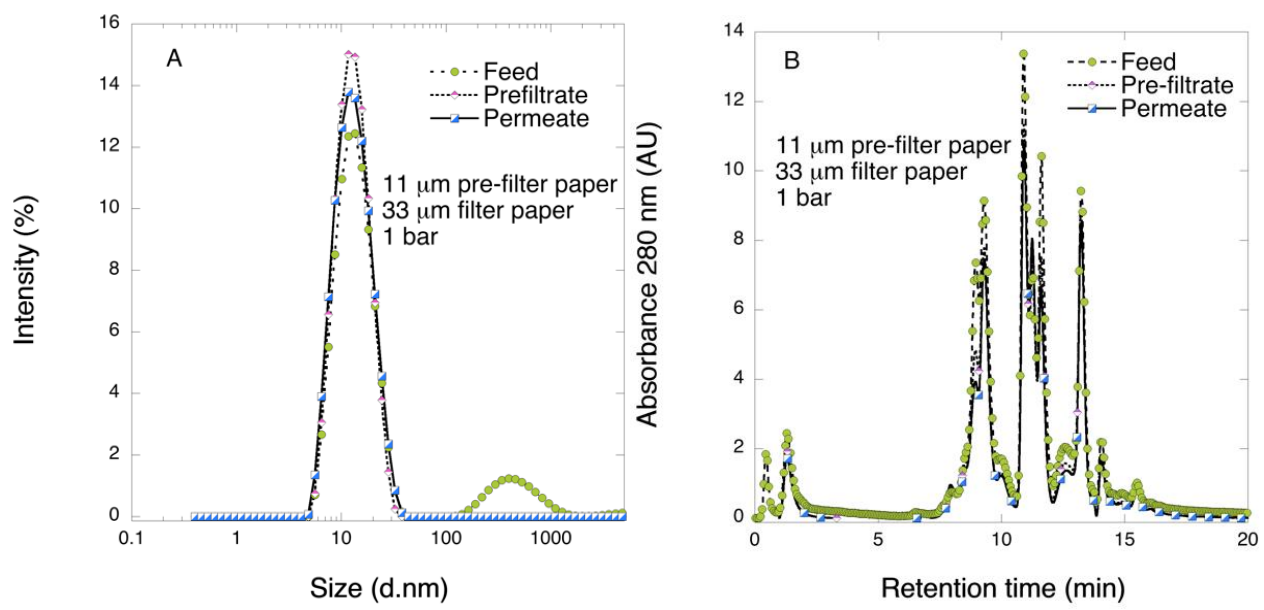

Figure 9. DLS (A) and SEHPLC (B) profiles of feed, pre-filtrate, and permeate samples after two-step filtration through $11 \mu \mathrm{m} / 33 \mu \mathrm{m}$ filter paper at 1 bar.

The results of the SDS-PAGE analysis for $11 \mu \mathrm{m} / 33 \mu \mathrm{m}$ filtration sequence are summarized in Figure 10. It is seen from the graph that the band intensities were reduced in the pre-filtrate and permeate samples as compared to the feed. It should be noted that in general the band intensities were reduced to a greater extent after pre-filtration with $11 \mu \mathrm{m}$ filter than with $6 \mu \mathrm{m}$ filter. The decrease of band intensity levels in the permeate sample passed through the $33 \mu \mathrm{m}$ filter after $11 \mu \mathrm{m}$ filtration was much less drastic than that for $6 \mu \mathrm{m} / 33 \mu \mathrm{m}$ filtration sequence. In particular, no significant changes 
were observed for bands 1, 2, and 4. For bands 3, 5, and 6 some intensity reduction was further detected in the permeate sample. LCMS analysis suggested that key coagulation factors IX, X, V as well as prothrombin were not removed following the two-step $11 \mu \mathrm{m} / 33 \mu \mathrm{m}$ filtration sequence (for details see Appendix Tables A1, A4 and A5).

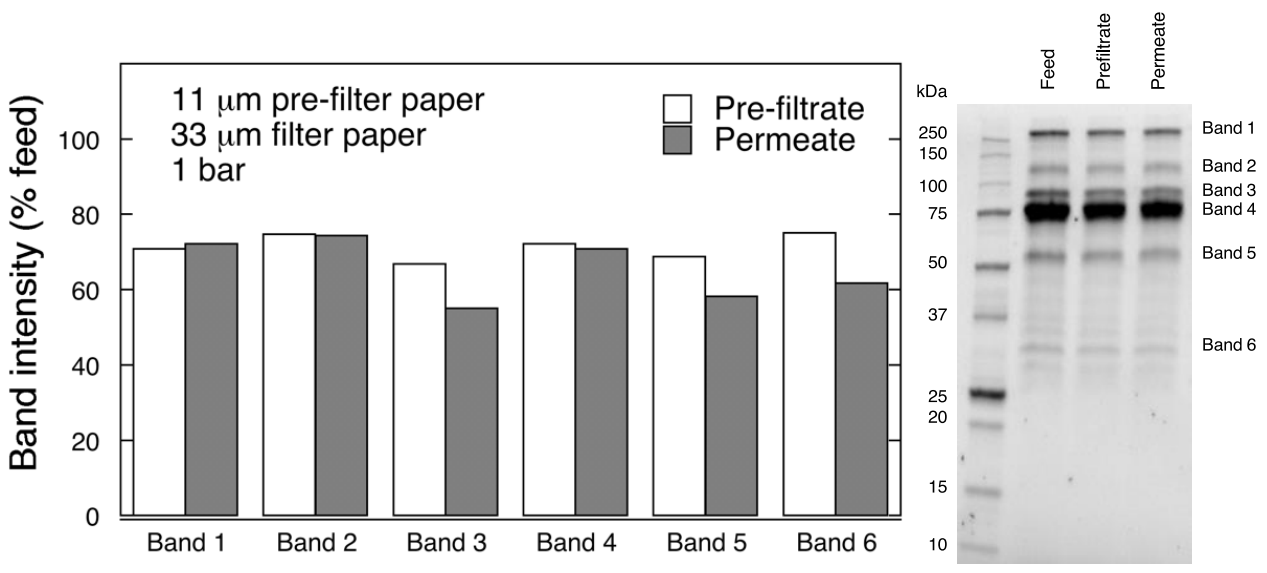

Figure 10. SDS-PAGE analysis of pre-filtrate and permeate fractions after 2-step filtration through $11 \mu \mathrm{m} / 33 \mu \mathrm{m}$ filter paper at 1 bar.

Based on the above results, it was concluded that pre-filtration with $11 \mu \mathrm{m}$ pre-filter removes the aggregates, which in turn greatly enhances the yield of the $33 \mu \mathrm{m}$ filtration. To confirm the high virus removal capacity of $33 \mu \mathrm{m}$ filter, the filter paper was loaded with much larger volume than that tested earlier, i.e., $175 \mathrm{~L} \mathrm{~m}^{-2}$. Figure 11 shows the result of the large load filtration. Following the filtration, no abrupt filter fouling was detected for the entire processed volume, although some flux decline could be observed (Figure 11A). Under the experimental conditions, it is estimated that Vmax of the process will be roughly around $500 \mathrm{~L} \mathrm{~m}^{-2}$, which is a drastic improvement from $20 \mathrm{~L} \mathrm{~m}^{-2}$ when filtering in a single-step process through $33 \mu \mathrm{m}$ filter paper. Furthermore, the filter paper showed high model small-size virus removal capacity, wherein LRV was $\geq 5$ in all collected fractions (Figure 11B). In particular, no detectable PFUs were observed at all up to $90 \mathrm{~L} \mathrm{~m}^{-2}$ load volume. In the last fractions only residual breakthrough (1-2 PFUs per agar plate, corresponding to 0.7 PFU mL ${ }^{-1}$ ) was detected. Thus, it was confirmed that the two-step $11 \mu \mathrm{m} / 33 \mu \mathrm{m}$ filtration provides enhanced throughput and good capacity to remove small-size virus without abrupt fouling even when challenged with a relatively large load.
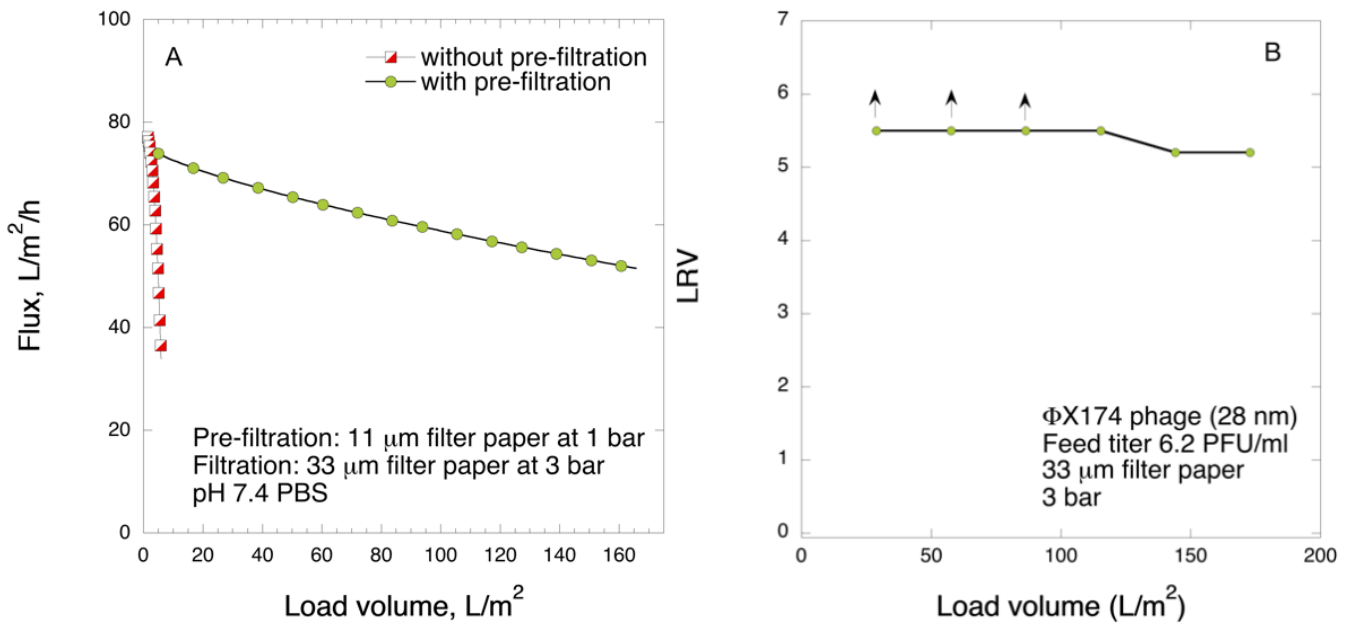

Figure 11. Observed flux for FIX-rich PCC permeate for 2-step $11 \mu \mathrm{m} / 33 \mu \mathrm{m}$ filtration with $175 \mathrm{~L} \mathrm{~m}^{-2}$ load volume at 3 bar (A) and LRV for $\Phi$ X174 phage (B). 


\section{Discussion}

In this article, the filtration of a highly challenging hematologic product was investigated. Considering that FIX-rich PCC inherently consists of many bioactive components and some impurities, the virus removal filtration of this product is difficult without fouling. The virus removal filtration of PCC was previously reported using Ultipor DV50 filters, which are dedicated for removal of large-size viruses but do not ensure viral safety against parvoviruses [2]. Filtration of PCC through small-size virus removal filters, e.g., Planova $15 \mathrm{~N}$, resulted in nearly $39 \%$ total protein loss and reduced FIX and FII activity, which was ascribed to presence of large-size complexes between clotting factors and high molecular weight impurities [14]. It was further reported in the same study that filtration of highly purified FIX through Planova $15 \mathrm{~N}$ not only did not result in the decrease of FIX activity but also improved its purity [14].

In this work, in order to achieve high virus removal capacity combined with reduced fouling, a tailored two-step process of filtration with nanocellulose-based filter paper was developed. In particular, sacrificial pre-filters with a thickness of 6 and $11 \mu \mathrm{m}$ were tested. The increased thickness of the filters resulted in tighter pore structure as detected by cryoporometry. The observed effect is explained as follows and illustrated in Figure 12. The mille-feuille filter paper consists of a stratified 3-dimensional network of cellulose nanofibers, producing a mesh-like stricture. The layered structure is illustrated in the side-view panel of Figure 12. Considering that the nanofibers are randomly distributed in each layer, the pores, which percolate throughout the entire depth of the filter, become tighter with increasing number of layers. The latter is reflected, e.g., in improved virus clearance properties with increased thickness or enhanced aggregate removal properties. Based on the results of PFU titrations of 27 and $70 \mathrm{~nm}$ phage particles, it was concluded that the tested filters show varying particle size rejection threshold as the thickness of the filter is increased. Thus, the observed effect is due to the combination of the receding pore size and depth effects (increased tortuosity). The latter enables using pre-filters with tailored cut-off to remove protein aggregates, which eventually results in improved flux through the dedicated virus removal filter.

$6 \mu \mathrm{m}$

$\frac{3}{\frac{3}{0}}$

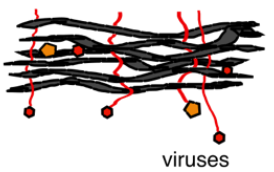

$\frac{3}{3}$
$11 \mu \mathrm{m}$
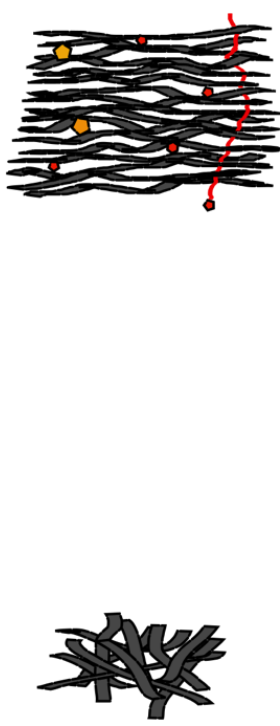

$33 \mu \mathrm{m}$
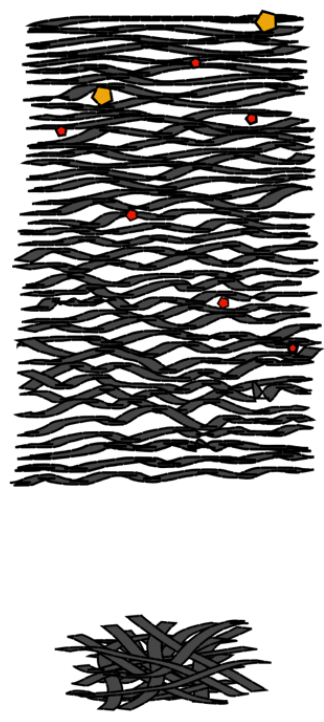

Figure 12. Illustration of the mechanism of virus removal with increased thickness of nanocellulose-based filter paper. Yellow symbols represent large-size model virus and red symbols represent small-size viruses. Increased thickness of the filter results in tighter pores and enhanced virus clearance. 
Overall, the two-step approach presented here is based on the size-exclusion principles and is therefore robust. It could thus further be adapted in the manufacturing of other protein-based pharmaceutics, too, including recombinant proteins wherein impurities in the form of host cell proteins may greatly affect the final yield of the biologics during virus removal nanofiltration.

\section{Conclusions}

A two-step process was developed to both enhance filtration capacity (25-fold) and achieve high clearance of small-size viruses (LRV $>5$ ) using appropriate pre-filter paper. Large-size aggregates were the main foulants in the feed solution, and by tailoring the properties of the pre-filters the foulants were efficiently removed. In particular, $11 \mu \mathrm{m} / 33 \mu \mathrm{m}$ filtration was found most suitable. The presented approach could potentially be applied for bioprocessing other protein-based drugs, both derived from plasma and produced by recombinant approaches. The article further provides new insights regarding the mechanism of virus removal in the nanocellulose-based filter paper, highlighting the combined effect of size exclusion and tortuosity of pore network.

Author Contributions: For research articles with several authors, a short paragraph specifying their individual contributions must be provided. The following statements should be used "Conceptualization, A.M. (Albert Mihranyan) and M.R.; methodology, A.M. (Albert Mihranyan), L.M., A.M. (Athanasios Mantas); supply of material, E.G., A.K.; formal analysis, L.M.; investigation, L.M, A.M. (Athanasios Mantas); resources, A.M. (Albert Mihranyan); data curation, L.M. and A.M. (Athanasios Mantas); writing—original draft preparation, L.M., A.M. (Albert Mihranyan); writing—review and editing, A.M. (Albert Mihranyan) L.M., R.M., A.K.; visualization, L.M.; supervision, A.M. (Albert Mihranyan); project administration, A.M. (Albert Mihranyan); funding acquisition, A.M. (Albert Mihranyan). All authors have read and agreed to the published version of the manuscript.

Funding: The project was funded by Knut and Alice Wallenberg Foundation (Bridge grant 2018.01141), Swedish Research Council [Vetenskapsrådet No. 2016-05715], and EU EIT Health Innovation by Idea program [VIREPAP 19104]. EIT Health is supported by the European Institute of Innovation and Technology (EIT), a body of the European Union that receives support from the European Union's Horizon 2020 Research and innovation program.

Acknowledgments: For LCMS analysis, the services of the Mass Spectrometry Based Proteomics Facility in Uppsala were used. The authors thank Ganna Shevchenko, Alexander Falk, and Jonas Bergquist for assistance in performing LCMS analysis.

Conflicts of Interest: The corresponding author (A.M. (Albert Mihranyan)) is the inventor behind the IP pertaining to virus removal filter paper.

Appendix A

Table A1. LCMS analysis of FIX-PCC feed solution.

\begin{tabular}{cccccc}
\hline Accession & Description & Score & Coverage & MW [kDa] & calc. pI \\
\hline P0C0L5 & Complement C4-B & 1920.89 & 76.38 & 192.6 & 7.27 \\
P0C0L4 & Complement C4-A & 1898.90 & 76.03 & 192.7 & 7.08 \\
P00734 & Prothrombin & 1767.89 & 75.56 & 70.0 & 5.90 \\
P19823 & Inter-alpha-trypsin inhibitor heavy chain H2 & 917.12 & 53.59 & 106.4 & 6.86 \\
P19827 & Inter-alpha-trypsin inhibitor heavy chain H1 & 685.72 & 55.76 & 101.3 & 6.79 \\
Q06033 & Inter-alpha-trypsin inhibitor heavy chain H3 & 257.18 & 40.22 & 99.8 & 5.74 \\
P02760 & Protein AMBP & 199.11 & 27.56 & 39.0 & 6.25 \\
P00740 & Coagulation factor IX & 134.15 & 47.29 & 51.7 & 5.47 \\
P00742 & Coagulation factor X & 59.86 & 38.52 & 54.7 & 5.94 \\
P02768 & Serum albumin & 48.49 & 28.41 & 69.3 & 6.28 \\
P49747 & Cartilage oligomeric matrix protein & 41.93 & 14.27 & 82.8 & 4.60 \\
P67936 & Tropomyosin alpha-4 chain & 32.67 & 39.11 & 28.5 & 4.69 \\
P01857 & Immunoglobulin heavy constant gamma 1 & 32.57 & 35.15 & 36.1 & 8.19 \\
P01834 & Immunoglobulin kappa constant & 30.33 & 39.25 & 11.8 & 6.52 \\
P07225 & Vitamin K-dependent protein S & 26.15 & 12.72 & 75.1 & 5.67 \\
P0DOY3 & Immunoglobulin lambda constant 3 & 21.63 & 78.30 & 11.3 & 7.24 \\
\hline
\end{tabular}


Table A1. Cont.

\begin{tabular}{|c|c|c|c|c|c|}
\hline Accession & Description & Score & Coverage & MW [kDa] & calc. pI \\
\hline B9A064 & Immunoglobulin lambda-like polypeptide 5 & 19.49 & 41.12 & 23.0 & 8.84 \\
\hline P01861 & Immunoglobulin heavy constant gamma 4 & 19.09 & 20.18 & 35.9 & 7.36 \\
\hline Q08380 & Galectin-3-binding protein & 18.16 & 9.74 & 65.3 & 5.27 \\
\hline P01876 & Immunoglobulin heavy constant alpha 1 & 15.74 & 24.93 & 37.6 & 6.51 \\
\hline P01859 & Immunoglobulin heavy constant gamma 2 & 13.53 & 21.78 & 35.9 & 7.59 \\
\hline P01871 & Immunoglobulin heavy constant mu & 8.22 & 4.64 & 49.4 & 6.77 \\
\hline Q14515 & SPARC-like protein 1 & 7.09 & 6.93 & 75.2 & 4.81 \\
\hline P04070 & Vitamin K-dependent protein C & 5.36 & 7.16 & 52.0 & 6.28 \\
\hline P12259 & Coagulation factor $\mathrm{V}$ & 1.95 & 0.81 & 251.5 & 6.05 \\
\hline P07237 & Protein disulfide-isomerase & 1.69 & 3.35 & 57.1 & 4.87 \\
\hline P10909 & Clusterin & 1.53 & 4.01 & 52.5 & 6.27 \\
\hline
\end{tabular}

Table A2. LCMS analysis of FIX-PCC pre-filtrate following filtration with $6 \mu \mathrm{m}$ filter.

\begin{tabular}{|c|c|c|c|c|c|}
\hline Accession & Description & Score & Coverage & MW [kDa] & calc. pI \\
\hline P0C0L5 & Complement C4-B & 2441.20 & 77.69 & 192.6 & 7.27 \\
\hline P19827 & Inter-alpha-trypsin inhibitor heavy chain $\mathrm{H} 1$ & 1154.64 & 54.34 & 101.3 & 6.79 \\
\hline P19823 & Inter-alpha-trypsin inhibitor heavy chain $\mathrm{H} 2$ & 1136.27 & 55.50 & 106.4 & 6.86 \\
\hline P00740 & Coagulation factor IX & 151.88 & 54.66 & 51.7 & 5.47 \\
\hline P00742 & Coagulation factor $X$ & 81.34 & 41.19 & 54.7 & 5.94 \\
\hline P02768 & Serum albumin & 60.16 & 37.44 & 69.3 & 6.28 \\
\hline P01834 & $\begin{array}{l}\text { Immunoglobulin kappa constant OS }=\text { Homo } \\
\text { sapiens }\end{array}$ & 48.66 & 81.31 & 11.8 & 6.52 \\
\hline P67936 & Tropomyosin alpha-4 chain & 31.98 & 36.29 & 28.5 & 4.69 \\
\hline P01861 & Immunoglobulin heavy constant gamma 4 & 30.25 & 28.13 & 35.9 & 7.36 \\
\hline P01860 & Immunoglobulin heavy constant gamma 3 & 28.46 & 27.06 & 41.3 & 7.90 \\
\hline P04004 & Vitronectin OS=Homo sapiens & 25.83 & 17.99 & 54.3 & 5.80 \\
\hline P0DOY2 & Immunoglobulin lambda constant 2 & 23.29 & 67.92 & 11.3 & 7.24 \\
\hline P07225 & Vitamin K-dependent protein $S$ & 21.00 & 11.83 & 75.1 & 5.67 \\
\hline P07359 & Platelet glycoprotein $\mathrm{Ib}$ alpha chain & 20.03 & 8.28 & 71.5 & 6.29 \\
\hline Q08380 & Galectin-3-binding protein & 17.21 & 12.82 & 65.3 & 5.27 \\
\hline P01876 & Immunoglobulin heavy constant alpha 1 & 15.47 & 19.55 & 37.6 & 6.51 \\
\hline P35443 & Thrombospondin- 4 & 14.04 & 4.79 & 105.8 & 4.68 \\
\hline P07900 & Heat shock protein HSP 90-alpha & 4.64 & 4.92 & 84.6 & 5.02 \\
\hline P61981 & $14-3-3$ protein gamma & 3.79 & 7.29 & 28.3 & 4.89 \\
\hline P63104 & 14-3-3 protein zeta/delta & 3.48 & 6.94 & 27.7 & 4.79 \\
\hline Q99436 & Proteasome subunit beta type- 7 & 2.11 & 8.30 & 29.9 & 7.68 \\
\hline$\widehat{\mathrm{P}} 25786$ & Proteasome subunit alpha type-1 & 1.66 & 7.98 & 29.5 & 6.61 \\
\hline
\end{tabular}


Table A3. LCMS analysis of FIX-PCC permeate following two-step filtration with $6 \mu \mathrm{m} / 33 \mu \mathrm{m}$ filters.

\begin{tabular}{|c|c|c|c|c|c|}
\hline Accession & Description & Score & Coverage & MW [kDa] & calc. pI \\
\hline P00734 & Prothrombin & 2759.75 & 73.31 & 70.0 & 5.90 \\
\hline P0C0L5 & Complement C4-B & 2411.85 & 78.61 & 192.6 & 7.27 \\
\hline P0C0L4 & Complement C4-A & 2379.43 & 75.80 & 192.7 & 7.08 \\
\hline P19823 & Inter-alpha-trypsin inhibitor heavy chain $\mathrm{H} 2$ & 1480.56 & 56.77 & 106.4 & 6.86 \\
\hline P19827 & Inter-alpha-trypsin inhibitor heavy chain $\mathrm{H} 1$ & 1167.61 & 54.45 & 101.3 & 6.79 \\
\hline Q06033 & Inter-alpha-trypsin inhibitor heavy chain $\mathrm{H} 3$ & 352.03 & 43.60 & 99.8 & 5.74 \\
\hline P02760 & Protein AMBP & 263.80 & 27.56 & 39.0 & 6.25 \\
\hline P00740 & Coagulation factor IX & 216.46 & 54.66 & 51.7 & 5.47 \\
\hline P00742 & Coagulation factor $X$ & 90.46 & 37.09 & 54.7 & 5.94 \\
\hline P02768 & Serum albumin & 62.34 & 36.45 & 69.3 & 6.28 \\
\hline P01857 & Immunoglobulin heavy constant gamma 1 & 47.83 & 39.09 & 36.1 & 8.19 \\
\hline P04004 & Vitronectin & 45.60 & 23.64 & 54.3 & 5.80 \\
\hline P49747 & Cartilage oligomeric matrix protein & 43.78 & 19.82 & 82.8 & 4.60 \\
\hline P51884 & Lumican OS=Homo sapiens & 43.31 & 42.90 & 38.4 & 6.61 \\
\hline P01834 & Immunoglobulin kappa constant & 40.16 & 49.53 & 11.8 & 6.52 \\
\hline P67936 & Tropomyosin alpha-4 chain & 39.83 & 40.32 & 28.5 & 4.69 \\
\hline P07359 & Platelet glycoprotein $\mathrm{Ib}$ alpha chain & 31.44 & 12.12 & 71.5 & 6.29 \\
\hline PODOY2 & Immunoglobulin lambda constant 2 & 29.10 & 75.47 & 11.3 & 7.24 \\
\hline Q08380 & Galectin-3-binding protein & 28.60 & 18.80 & 65.3 & 5.27 \\
\hline P01861 & Immunoglobulin heavy constant gamma 4 & 28.41 & 22.02 & 35.9 & 7.36 \\
\hline P01876 & Immunoglobulin heavy constant alpha 1 & 23.24 & 25.78 & 37.6 & 6.51 \\
\hline B9A064 & Immunoglobulin lambda-like polypeptide 5 & 22.01 & 38.79 & 23.0 & 8.84 \\
\hline P07225 & Vitamin K-dependent protein S & 20.55 & 14.35 & 75.1 & 5.67 \\
\hline P01859 & Immunoglobulin heavy constant gamma 2 & 19.80 & 24.23 & 35.9 & 7.59 \\
\hline Q14515 & SPARC-like protein 1 & 19.72 & 9.19 & 75.2 & 4.81 \\
\hline P35443 & Thrombospondin- 4 & 14.73 & 4.79 & 105.8 & 4.68 \\
\hline P12259 & Coagulation factor $\mathrm{V}$ & 8.97 & 2.34 & 251.5 & 6.05 \\
\hline P13591 & Neural cell adhesion molecule 1 & 8.03 & 4.55 & 94.5 & 4.87 \\
\hline P12814 & Alpha-actinin-1 & 7.56 & 3.48 & 103.0 & 5.41 \\
\hline P0CG38 & POTE ankyrin domain family member I & 7.35 & 3.07 & 121.2 & 6.21 \\
\hline P01871 & Immunoglobulin heavy constant mu & 7.06 & 8.61 & 49.4 & 6.77 \\
\hline P04070 & Vitamin K-dependent protein C & 5.93 & 10.63 & 52.0 & 6.28 \\
\hline P16070 & CD44 antigen & 5.80 & 2.70 & 81.5 & 5.33 \\
\hline P61981 & $14-3-3$ protein gamma & 5.53 & 10.93 & 28.3 & 4.89 \\
\hline P07900 & Heat shock protein HSP 90-alpha & 3.08 & 3.42 & 84.6 & 5.02 \\
\hline P01023 & Alpha-2-macroglobulin & 2.56 & 1.76 & 163.2 & 6.46 \\
\hline Q14185 & Dedicator of cytokinesis protein 1 & 1.99 & 1.66 & 215.2 & 7.56 \\
\hline Q562R1 & Beta-actin-like protein 2 & 1.78 & 7.71 & 42.0 & 5.59 \\
\hline
\end{tabular}

Table A4. LCMS analysis of FIX-PCC pre-filtrate following filtration with $11 \mu \mathrm{m}$ filter.

\begin{tabular}{cccccc}
\hline Accession & Description & Score & Coverage & MW [kDa] & calc. pI \\
\hline P00734 & Prothrombin & 2458.17 & 67.20 & 70.0 & 5.90 \\
P0C0L5 & Complement C4-B & 2389.47 & 80.68 & 192.6 & 7.27 \\
P0C0L4 & Complement C4-A & 2352.05 & 79.59 & 192.7 & 7.08 \\
P19823 & Inter-alpha-trypsin inhibitor heavy chain H2 & 1268.03 & 56.87 & 106.4 & 6.86 \\
P19827 & Inter-alpha-trypsin inhibitor heavy chain H1 & 1122.57 & 59.50 & 101.3 & 6.79 \\
Q06033 & Inter-alpha-trypsin inhibitor heavy chain H3 & 352.56 & 40.00 & 99.8 & 5.74 \\
P02760 & Protein AMBP & 285.56 & 27.56 & 39.0 & 6.25 \\
P00740 & Coagulation factor IX & 182.33 & 57.27 & 51.7 & 5.47 \\
P00742 & Coagulation factor X & 80.33 & 41.19 & 54.7 & 5.94 \\
P01834 & Immunoglobulin kappa constant & 54.45 & 54.21 & 11.8 & 6.52 \\
P49747 & Cartilage oligomeric matrix protein & 53.77 & 24.31 & 82.8 & 4.60 \\
P01857 & Immunoglobulin heavy constant gamma 1 & 45.54 & 43.33 & 36.1 & 8.19 \\
P02768 & Serum albumin & 44.26 & 25.78 & 69.3 & 6.28 \\
P07359 & Platelet glycoprotein Ib alpha chain & 33.83 & 16.56 & 71.5 & 6.29 \\
P01860 & Immunoglobulin heavy constant gamma 3 & 33.53 & 31.83 & 41.3 & 7.90 \\
P0DOY3 & Immunoglobulin lambda constant 3 & 33.11 & 70.75 & 11.3 & 7.24 \\
\hline
\end{tabular}


Table A4. Cont.

\begin{tabular}{cccccc}
\hline Accession & Description & Score & Coverage & MW [kDa] & calc. pI \\
\hline P01861 & Immunoglobulin heavy constant gamma 4 & 30.81 & 23.85 & 35.9 & 7.36 \\
P04004 & Vitronectin & 27.21 & 23.64 & 54.3 & 5.80 \\
P51884 & Lumican & 26.62 & 35.50 & 38.4 & 6.61 \\
P01876 & Immunoglobulin heavy constant alpha 1 & 25.67 & 29.18 & 37.6 & 6.51 \\
Q08380 & Galectin-3-binding protein & 25.15 & 17.78 & 65.3 & 5.27 \\
P67936 & Tropomyosin alpha-4 chain & 25.00 & 44.35 & 28.5 & 4.69 \\
P01859 & Immunoglobulin heavy constant gamma 2 & 17.12 & 25.77 & 35.9 & 7.59 \\
P07225 & Vitamin K-dependent protein S & 16.75 & 9.62 & 75.1 & 5.67 \\
P35443 & Thrombospondin-4 & 16.66 & 5.52 & 105.8 & 4.68 \\
P12259 & Coagulation factor V & 10.18 & 1.98 & 251.5 & 6.05 \\
P04070 & Vitamin K-dependent protein C & 7.36 & 5.86 & 52.0 & 6.28 \\
P16070 & CD44 antigen & 5.64 & 2.70 & 81.5 & 5.33 \\
P13591 & Neural cell adhesion molecule 1 & 5.50 & 1.75 & 94.5 & 4.87 \\
P22105 & Tenascin-X & 4.42 & 2.33 & 458.1 & 5.17 \\
Q99436 & Proteasome subunit beta type-7 & 4.03 & 8.30 & 29.9 & 7.68 \\
P12814 & Alpha-actinin-1 & 3.68 & 2.35 & 103.0 & 5.41 \\
P27348 & 14-3-3 protein theta & 3.53 & 6.53 & 27.7 & 4.78 \\
P07900 & Heat shock protein HSP 90-alpha & 1.73 & 3.14 & 84.6 & 5.02 \\
\hline
\end{tabular}

Table A5. LCMS analysis of FIX-PCC permeate following two-step filtration with $11 \mu \mathrm{m} / 33 \mu \mathrm{m}$ filters.

\begin{tabular}{|c|c|c|c|c|c|}
\hline Accession & Description & Score & Coverage & MW [kDa] & calc. pI \\
\hline P0C0L5 & Complement C4-B & 2266.18 & 76.26 & 192.6 & 7.27 \\
\hline P0C0L4 & Complement C4-A & 2219.29 & 76.26 & 192.7 & 7.08 \\
\hline P00734 & Prothrombin & 2011.89 & 71.54 & 70.0 & 5.90 \\
\hline P19823 & Inter-alpha-trypsin inhibitor heavy chain $\mathrm{H} 2$ & 1452.50 & 55.81 & 106.4 & 6.86 \\
\hline P19827 & Inter-alpha-trypsin inhibitor heavy chain $\mathrm{H} 1$ & 1205.49 & 54.23 & 101.3 & 6.79 \\
\hline Q06033 & Inter-alpha-trypsin inhibitor heavy chain $\mathrm{H} 3$ & 256.28 & 46.97 & 99.8 & 5.74 \\
\hline P02760 & Protein AMBP & 213.99 & 25.57 & 39.0 & 6.25 \\
\hline P00740 & Coagulation factor IX & 114.46 & 45.55 & 51.7 & 5.47 \\
\hline P00742 & Coagulation factor $X$ & 74.31 & 36.07 & 54.7 & 5.94 \\
\hline P02768 & Serum albumin & 46.51 & 27.91 & 69.3 & 6.28 \\
\hline P01857 & Immunoglobulin heavy constant gamma 1 & 45.77 & 43.33 & 36.1 & 8.19 \\
\hline P49747 & Cartilage oligomeric matrix protein & 34.16 & 20.08 & 82.8 & 4.60 \\
\hline P01834 & Immunoglobulin kappa constant & 32.23 & 49.53 & 11.8 & 6.52 \\
\hline P67936 & Tropomyosin alpha-4 chain & 27.70 & 37.90 & 28.5 & 4.69 \\
\hline P01860 & Immunoglobulin heavy constant gamma 3 & 27.37 & 25.99 & 41.3 & 7.90 \\
\hline P51884 & Lumican & 25.59 & 39.94 & 38.4 & 6.61 \\
\hline P01861 & Immunoglobulin heavy constant gamma 4 & 24.73 & 26.61 & 35.9 & 7.36 \\
\hline P01859 & Immunoglobulin heavy constant gamma 2 & 23.14 & 32.82 & 35.9 & 7.59 \\
\hline P04004 & Vitronectin & 22.83 & 23.43 & 54.3 & 5.80 \\
\hline P07359 & Platelet glycoprotein $\mathrm{Ib}$ alpha chain & 21.45 & 9.82 & 71.5 & 6.29 \\
\hline P07225 & Vitamin K-dependent protein S & 20.38 & 10.65 & 75.1 & 5.67 \\
\hline PODOY2 & Immunoglobulin lambda constant 2 & 17.99 & 37.74 & 11.3 & 7.24 \\
\hline Q08380 & Galectin-3-binding protein & 17.44 & 15.73 & 65.3 & 5.27 \\
\hline P01876 & Immunoglobulin heavy constant alpha 1 & 17.06 & 25.78 & 37.6 & 6.51 \\
\hline P35443 & Thrombospondin-4 & 9.76 & 4.79 & 105.8 & 4.68 \\
\hline P12259 & Coagulation factor $\mathrm{V}$ & 8.36 & 2.11 & 251.5 & 6.05 \\
\hline P04070 & Vitamin K-dependent protein C & 7.60 & 8.89 & 52.0 & 6.28 \\
\hline P61981 & $14-3-3$ protein gamma & 5.93 & 10.53 & 28.3 & 4.89 \\
\hline P16070 & CD44 antigen & 4.96 & 2.70 & 81.5 & 5.33 \\
\hline Q99436 & Proteasome subunit beta type-7 & 4.05 & 8.30 & 29.9 & 7.68 \\
\hline Q14515 & SPARC-like protein 1 & 4.05 & 3.77 & 75.2 & 4.81 \\
\hline P07900 & Heat shock protein HSP 90-alpha & 2.46 & 2.60 & 84.6 & 5.02 \\
\hline P01023 & Alpha-2-macroglobulin & 1.97 & 1.49 & 163.2 & 6.46 \\
\hline P22105 & Tenascin- $\mathrm{X}$ OS $=$ Homo sapiens & 1.66 & 0.66 & 458.1 & 5.17 \\
\hline P13591 & Neural cell adhesion molecule 1 & 0.00 & 1.75 & 94.5 & 4.87 \\
\hline Q5UIP0 & Telomere-associated protein RIF1] & 0.00 & 1.62 & 274.3 & 5.52 \\
\hline
\end{tabular}




\section{References}

1. EMA. Guideline on Clinical Investigation of Recombinant and Human Plasma-derived Factor IX Products. EMA/CHMP/BPWP/144552/2009; 2011. Available online: https://www.ema.europa.eu/en/documents/ scientific-guideline/guideline-clinical-investigation-recombinant-human-plasma-derived-factor-ixproducts_en.pdf (accessed on 25 March 2020).

2. Josić, D.; Hoffer, L.; Buchacher, A.; Schwinn, H.; Frenzel, W.; Biesert, L.; Klöcking, H.-P.; Hellstern, P. Manufacturing of a Prothrombin Complex Concentrate Aiming at Low Thrombogenicity. Thromb. Res. 2000, 100, 433-441. [CrossRef]

3. Josić, D.; Hoffer, L.; Buchacher, A. Preparation of vitamin K-dependent proteins, such as clotting factors II, VII, IX and X and clotting inhibitor Protein, C. J. Chromatogr. B. 2003, 790, 183-197. [CrossRef]

4. Burnouf, T.; Michalski, C.; Goudemand, M.; Huart, J.J. Properties of a Highly Purified Human Plasma Factor IX:c Therapeutic Concentrate Prepared by Conventional Chromatography. Vox. Sang. 1989, 57, 225-232. [CrossRef] [PubMed]

5. Teitel, J.M. Safety of coagulation factor concentrates. Haemophilia 1998, 4, 393-401. [PubMed]

6. EMA. Guideline on Plasma-derived Medicinal Products. EMA/CHMP/BWP/706271/2010; 2011. Available online: https://www.ema.europa.eu/en/documents/scientific-guideline/guideline-plasma-derived-medicinalproducts_en.pdf (accessed on 25 March 2020).

7. Klamroth, R.; Gröner, A.; Simon, T.L. Pathogen inactivation and removal methods for plasma-derived clotting factor concentrates. Transfusion 2014, 54, 1406-1417. [CrossRef] [PubMed]

8. Grancha, S.; Herring, S.; Paéz, A.; Ristol, P.; Jorquera, J.I. Factor IX; John Wiley \& Sons, Inc.: Hoboken, NJ, USA, 2012; pp. 81-92. [CrossRef]

9. Koenderman, A.H.L.; ter Hart, H.G.J.; Prins-de Nijs, I.M.M.; Bloem, J.; Stoffers, S.; Kempers, A.; Derksen, G.J.; Al, B.; Dekker, L.; Over, J. Virus safety of plasma products using $20 \mathrm{~nm}$ instead of $15 \mathrm{~nm}$ filtration as virus removing step. Biologicals 2012, 40,473-481. [CrossRef]

10. Roberts, P.L.; Feldman, P.; Crombie, D.; Walker, C.; Lowery, K. Virus removal from factor IX by filtration: Validation of the integrity test and effect of manufacturing process conditions. Biologicals 2010, 38, 303-310. [CrossRef]

11. Winkler, C.J.; Jorba, N.; Shitanishi, K.T.; Herring, S.W. Protein sieving characteristics of sub-20-nm pore size filters at varying ionic strength during nanofiltration of Coagulation Factor IX. Biologicals 2013, 41, 176-183. [CrossRef]

12. Caballero, S.; Diez, J.M.; Belda, F.J.; Otegui, M.; Herring, S.; Roth, N.J.; Lee, D.; Gajardo, R.; Jorquera, J.I. Robustness of nanofiltration for increasing the viral safety margin of biological products. Biologicals 2014, 42, 79-85. [CrossRef]

13. Johnston, A.; Macgregor, A.; Borovec, S.; Hattarki, M.; Stuckly, K.; Anderson, D.; Goss, N.H.; Oates, A.; Uren, E. Inactivation and Clearance of Viruses During the Manufacture of High Purity Factor IX. Biologicals 2000, 28, 129-136. [CrossRef]

14. Menconi, M.C.; Maggi, F.; Zakrzewska, K.; Salotti, V.; Giovacchini, P.; Farina, C.; Andreoli, E.; Corcioli, F.; Bendinelli, M.; Azzi, A. Effectiveness of nanofiltration in removing small non-enveloped viruses from three different plasma-derived products. Transfus. Med. 2009, 19, 213-217. [CrossRef] [PubMed]

15. Russo, R.; Focà, G.; Rega, C.; Sandomenico, A.; Doti, N.; Mori, F.; Maddaluno, M.; Farina, C.; Ruvo, M.; Chambery, A. A multianalytical approach to investigate the effect of nanofiltration on plasma-derived factor IX clinical lots. Anal. Biochem. 2018, 542, 1-10. [CrossRef] [PubMed]

16. Hoffer, L.; Schwinn, H.; Biesert, L.; Josić, D. Improved virus safety and purity of a chromatographically produced Factor IX concentrate by nanofiltration. J. Chromatogr. B. 1995, 669, 187-196. [CrossRef]

17. Kim, I.S.; Choi, Y.W.; Kang, Y.; Sung, H.M.; Sohn, K.W.; Kim, Y.S. Improvement of virus safety of an antihemophilc factor IX by virus filtration process. J. Microbiol. Biotechnol. 2008, 18, 1317-1325. [PubMed]

18. Clifton, J.; Huang, F.; Gaso-Sokac, D.; Brilliant, K.; Hixson, D.; Josić, D. Use of proteomics for validation of the isolation process of clotting factor IX from human plasma. J. Proteom. 2010, 73, 678-688. [CrossRef]

19. Jorba, N.; Shitanishi, K.T.; Winkler, C.J.; Herring, S.W. Virus removal capacity at varying ionic strength during nanofiltration of AlphaNine ${ }^{\circledR}$ SD. Biologicals 2014, 42, 290-293. [CrossRef]

20. Hoffer, L.; Schwinn, H.; Josić, D. Production of highly purified clotting factor IX by a combination of different chromatographic methods. J. Chromatogr. A 1999, 844, 119-128. [CrossRef] 
21. Dahlbäck, B. Purification of human C4b-binding protein and formation of its complex with vitamin K-dependent protein S. Biochem. J. 1983, 209, 847. [CrossRef]

22. Dahlbäck, B.; Smith, C.A.; Müller-Eberhard, H.J. Visualization of human C4b-binding protein and its complexes with vitamin K-dependent protein S and complement protein C4b. Proc. Natl. Acad. Sci. USA 1983, 80, 3461.

23. Perkins, S.J.; Chung, L.P.; Reid, K.B.M. Unusual ultrastructure of complement-component-C4b-binding protein of human complement by synchrotron X-ray scattering and hydrodynamic analysis. Biochem. J. 1986, 233, 799. [CrossRef]

24. Blom, A.M. Structural and functional studies of complement inhibitor C4b-binding protein. Biochem. Soc. Trans. 2002, 30, 978. [CrossRef] [PubMed]

25. Hillarp, A.; Hessing, M.; Dahlbäck, B. Protein S binding in relation to the subunit composition of human C4b-binding protein. FEBS Lett. 1989, 259, 53-56. [CrossRef]

26. Josić, D.; Brown, M.K.; Huang, F.; Lim, Y.-P.; Rucevic, M.; Clifton, J.G.; Hixson, D.C. Proteomic characterization of inter-alpha inhibitor proteins from human plasma. Proteomics 2006, 6, 2874-2885. [CrossRef] [PubMed]

27. Josić, D.; Kannicht, C.; Löster, K.; Pock, K.; Iberer, G.; Buchacher, A. Vitronectin in clotting factor IX concentrates. Haemophilia 2001, 7, 250-257. [CrossRef] [PubMed]

28. Høgåsen, K.; Mollnes, T.E.; Harboe, M. Heparin-binding properties of vitronectin are linked to complex formation as illustrated by in vitro polymerization and binding to the terminal complement complex. J. Biol. Chem. 1992, 267, 23076-23082. [PubMed]

29. Izumi, M.; Yamada, K.M.; Hayashi, M. Vitronectin exists in two structurally and functionally distinct forms in human plasma. Biochim. Biophys Acta Gen. Subj. 1989, 990, 101-108. [CrossRef]

30. Dahlbäck, B.; Podack, E.R. Characterization of human S protein, an inhibitor of the membrane attack complex of complement. Demonstration of a free reactive thiol group. Biochemistry 1985, 24, 2368-2374. [CrossRef]

31. Metreveli, G.; Wagberg, L.; Emmoth, E.; Belák, S.; Strømme, M.; Mihranyan, A. A size-exclusion nanocellulose filter paper for virus removal. Adv. Healthc. Mater. 2014, 3, 1546-1550, 1524. [CrossRef]

32. Gustafsson, S.; Lordat, P.; Hanrieder, T.; Asper, M.; Schaefer, O.; Mihranyan, A. Mille-feuille paper: A novel type of filter architecture for advanced virus separation applications. Mater. Horiz 2016, 3, 320-327. [CrossRef]

33. Quellmalz, A.; Mihranyan, A. Citric Acid Cross-Linked Nanocellulose-Based Paper for Size-Exclusion Nanofiltration. ACS Biomater. Sci. Eng. 2015, 1, 271-276. [CrossRef]

34. Gustafsson, S.; Mihranyan, A. Strategies for Tailoring the Pore-Size Distribution of Virus Retention Filter Papers. ACS Appl. Mater. Interfaces 2016, 8, 13759-13767. [CrossRef] [PubMed]

35. Asper, M.; Hanrieder, T.; Quellmalz, A.; Mihranyan, A. Removal of xenotropic murine leukemia virus by nanocellulose based filter paper. Biologicals 2015, 43, 452-456. [CrossRef] [PubMed]

36. Gustafsson, S.; Westermann, F.; Hanrieder, T.; Jung, L.; Ruppach, H.; Mihranyan, A. Comparative Analysis of Dry and Wet Porometry Methods for Characterization of Regular and Cross-Linked Virus Removal Filter Papers. Membranes 2019, 9, 1. [CrossRef] [PubMed]

37. Gustafsson, O.; Gustafsson, S.; Manukyan, L.; Mihranyan, A. Significance of Brownian Motion for Nanoparticle and Virus Capture in Nanocellulose-Based Filter Paper. Membranes 2018, 8, 90. [CrossRef] [PubMed]

38. Manukyan, L.; Li, P.; Gustafsson, S.; Mihranyan, A. Growth media filtration using nanocellulose-based virus removal filter for upstream biopharmaceutical processing. J. Memb. Sci. 2019, 572, 464-474. [CrossRef]

39. Manukyan, L.; Padova, J.; Mihranyan, A. Virus removal filtration of chemically defined Chinese Hamster Ovary cells medium with nanocellulose-based size exclusion filter. Biologicals 2019, 1045-1056. [CrossRef]

40. Wu, L.; Manukyan, L.; Mantas, A.; Mihranyan, A. Nanocellulose-Based Nanoporous Filter Paper for Virus Removal Filtration of Human Intravenous Immunoglobulin. ACS Appl. Nano. Mater. 2019, 2, 6352-6359. [CrossRef]

41. Landry, M.R. Thermoporometry by differential scanning calorimetry: Experimental considerations and applications. Thermochim. Acta 2005, 433, 27-50. [CrossRef]

(C) 2020 by the authors. Licensee MDPI, Basel, Switzerland. This article is an open access article distributed under the terms and conditions of the Creative Commons Attribution (CC BY) license (http://creativecommons.org/licenses/by/4.0/). 